\title{
REFORMING THE COMMON LAW RULE AGAINST PERPETUITIES
}

\author{
ROBERT J. LYNN†
}

$I^{1}$ N 1959 the Washington legislature enacted a statute that applies both "wait and see" and "cy pres" principles to the provisions of a trust instrument violating the common law Rule Against Perpetuities. ${ }^{1}$

Although the statute is unique, the notions it incorporates are not new. But in one respect it creates a differentiation of property interests not worth encouraging. The statute applies to beneficial interests. Legal interests are unaffected by the statute unless originating in an instrument creating a trust or unless accorded equivalent treatment by Washington courts as a matter of consistency in perpetuities cases. ${ }^{2}$

If reformation of the Rule is attainable only through legislation as ineptly drawn as the Washington statute, curing the defects that the Rule unquestion-

$\dagger$ Professor of Law, Ohio State University.

1 The first three sections of the Washington statute are as follows:

"11.98.010 Violation of rule against perpetuities by instrument-Periods during which trust not invalid. If any provision of an instrument creating a trust shall violate the rule against perpetuities, neither such provision nor any other provisions of the trust shall thereby be rendered invalid during any of the following periods:

"(1) The twenty-one years following the effective date of the instrument.

"(2) The period measured by any life or lives in being or conceived at the effective date of the instrument if by the terms of the instrument the trust is to continue for such life or lives.

"(3) The period measured by any portion of any life or lives in being or conceived at the effective date of the instrument if by the terms of the instrument the trust is to continue for such portion of such life or lives; and

"(4) The twenty-one years following the expiration of the periods specified in (2) and (3) above. [1959 c $146 \$ 1$.

"11.98.020 Distribution of assets and vesting of interest during period trust not invalid. If, during any period in which an instrument creating a trust or any provision thereof is not to be rendered invalid by the rule against perpetuities, any of the trust assets should by the terms of the instrument become distributable or any beneficial interest therein should by the terms of the instrument become vested, such assets shall be distributed and such beneficial interest shall validly vest in accordance with the instrument. [1959 c $146 \$ 2$.]

"11.98.030 Distribution of assets at expiration of period. If, at the expiration of any period in which an instrument creating a trust or any provision thereof is not to be rendered invalid by the rule against perpetuities, any of the trust assets have not by the terms of the trust instrument become distributable or vested, then such assets shall be then distributed as the superior court having jurisdiction shall direct, giving effect to the general intent of the creator of the trust. [1959 c $146 \S 3]$.

WASH. ReV. CODE tit. 11, $\S \$ 11.98 .010-.030$ (1959).

In its most sweeping form the "wait and see" doctrine uses actual events rather than possibilities to test limitations under the Rule. Brégy, A Defense of Pennsylvania's Statute on Perpetuities, 23 TEMP. L.Q. 313 (1950). Cy pres requires a court to approximate the intention of the donor within the limits of the Rule if his attempted disposition violates the Rule. Leach, Perpetuities Reform by Legislation, 70 L.Q. REv. 478, 490 (1954).

2 Cross, Rule Against Perpetuities in Trust Dispositions, 34 Wash. L. Rev. 330 (1959). 
ably has may prove as bad as living with them. Even well-drafted perpetuities legislation leaves much to be desired from a policy standpoint. ${ }^{3}$ Must the price of improvement include perpetuation of indefensible distinctions between kinds of property and among kinds of future interests?

That the Rule is fair game is usually assumed. It has been successfully attacked at its most vulnerable points. 4 In classic form its defenders are few. 5 It is one thing, however, to attack the Rule insofar as it is inherently defective. It is quite another to attack it insofar as it is badly handled by courts. And it is patently misleading to imply that the Rule must be fashioned in such a way that it can be flouted by a donor, however unreasonable, or violated with impunity by a draftsman, however inept. There is still something to be said for keeping madmen with property in check, both directly, by striking down dis-

${ }^{3}$ In Connecticut, Maine, and Massachusetts executory interests are equated with possibilities of reverter and rights of entry to a limited extent, but not entirely. CONN. GEN. STAT. ANN. tit. 45, §§ 45-95 to 45-99 (1960); ME. REv. Srat. ANN. ch. 160, \$§ 27-33 (Supp. 1959); Mass. ANN. Laws ch. 184A, \$§ 1-6 (1955). See Note, 54 Mich. L. Rev. 723 (1956). Section 3 of the Massachusetts Act is as follows:

"A fee simple determinable in land or a fee simple in land subject to a right of entry for condition broken shall become a fee simple absolute if the specified contingency does not occur within thirty years from the date when such fee simple determinable or such fee simple subject to a right of entry becomes possessory. If such contingency occurs within said thirty years the succeeding interest, which may be an interest in a person other than the person creating the interest or his heirs, shall become possessory or the right of entry exercisable notwithstanding the rule against perpetuities. But if a fee simple determinable in land or a fee simple in land subject to a right of entry for condition broken is so limited that the specified contingency must occur, if at all, within the period of the rule against perpetuities, said interests shall take effect as limited. This section shall not apply where both such fee simple determinable and such succeeding interest, or both such fee simple and such right of entry are for public, charitable or religious purposes; nor shall it apply to a deed, gift or grant of the commonwealth or any political subdivision thereof."

The differentiations among the three interests may be demonstrated through two hypothetical cases. A conveys "to the Church in fee simple, but if the land shall cease to be used for church purposes then to B and his heirs." The executory interest in B is void both at common law and under the new legislation. The Church takes a fee simple. A conveys "to the Church so long as used for church purposes, then to B and his heirs." Under the new legislation, B takes if the contingency occurs within 30 years "from the date when such fee simple determinable . . . becomes possessory." If the contingency does not occur within 30 years, the Church takes a fee simple.

Professor Leach thought differentiation a reasonable price to pay for enactment of reform legislation. Leach, Perpetuities Legislation, Massachusetts Style, 67 Harv. L. REv. 1349,1355 (1954). Under the new Kentucky legislation equivalence appears to be complete. Ky. Acts 1960 , S. 180, $\S 4,5$.

4 Professor Leach's direct attacks are available in several sources. Leach, Perpetuities Reform by Legislation: England, 70 HARv. L. REv. 1411 (1957); Leach, Perpetuities Legislation, Massachusetts Style, 67 HARv. L. Rev. 1349 (1954); Leach, Perpetuities in Perspective: Ending the Rule's Reign of Terror, 65 HARv. L. REv. 721 (1952); 6 AMERICAN LAW OF ProperTy \$\$ 24.1-24.63 (Casner ed. 1952, prepared in collaboration with Mr. Owen Tudor); Morris \& Leach, The Rule AgaInst PerpetuItIes (1956). His most recent remarks are found in Comment, 73 HARv. L. Rev. 1318 (1960), and Leach, Perpetuities Legislation: Hail Pennsylvania!, 108 U. PA. L. Rev. 1124 (1960).

${ }^{5}$ Mechem, Further Thoughts on the Pennsylvania Perpetuities Legislation, 107 U. PA. L. REv. 965, 966 (1959). 
positions that violate the Rule, ${ }^{6}$ and indirectly, by alerting draftsmen to the dangers inherent in intemperate, indiscriminate creation of future interests. 7

In this paper it is proposed first to summarize briefly the major developments in the law that have occurred relatively recently; second, to demonstrate in part that the need for reform is less pressing now than it was a half century ago; and last, to suggest approaches that property lawyers might follow in making the Rule an effective instrument for policing the transmission of wealth from generation to generation.

I

During the past fifteen years legislative change in the common law Rule has proceeded along the following lines:

1) The Rule has been abandoned altogether. 8

2) The classic "possibilities" test for the validity of contingent future interests under the Rule has been abandoned and an "actualities" ("wait and see") test has been adopted. 9

3) The classic "possibilities" test for the validity of contingent future interests under the Rule has been abandoned to a limited extent and an "actualities" test has been adopted to a limited extent.10

4) The classic "possibilities" test for the validity of contingent future interests under the Rule has been abandoned to a limited extent and a preferred rule of construction has been adopted with respect to particular possibilities.11

5) The functional equivalence of future interests commonly differentiated has received limited recognition, and the favored treatment accorded some future interests under the Rule has been withdrawn by indirection.12

6) A judicial re-ordering of interests in order to comply with the require-

${ }^{6}$ In Clayton v. Burch, 239 N.C. 386,80 S.E. 2 d 29 (1954), a devise of realty to the "Body ars" of a grandson of the testator "down to the Tenth Jenneration" failed under the Rule.

7 Bordwell, Perpetuities from the Point of View of the Draughtsman, 11 RUTGERs L. REV. 429 (1956).

8 IDAHo Code ANN. § 55-111 (1957).

9 Pa. Stat. Ann. tit. 20, $\$ 301.4$ (1950); VT. Stat. ANN. tit. 27, §§ 501-03 (1959); Ky. Acts 1960, S. 180, $\S \S 1,2$. New Hampshire adopted the "wait and see" test by judicial decision. Merchants Nat'l Bk. v. Curtis, 98 N.H. 225, 97 A.2d 207 (1953).

10 ConN. Gen. StAT. ANN. tit. 45, §§45-95 to 45-99 (1960); MD. Code ANn. art. 16, §197A (Supp. 1960); Me. Rev. Stat. ANN. ch. 160, §§ 27-33 (Supp. 1959); Mass. ANN. Laws ch. 184 A, §§ 1-6 (1955). Note, 54 Mich. L. REv. 723 (1950; Newhall, Humanizing Rule Against Perpetuities, 93 TRUSTs \& Estates 724 (1954); Leach, supra note 3.

11 Ill. Rev. StAT. ch. 30, § 153 (a) (Supp. 1959); Note, 55 MrCh. L. Rev. 1040 (1957). The Kentucky version of the Illinois act was repealed in 1960 when Kentucky adopted its "wait and see" and "cy pres" statute. Ky. Acts 1960, S. 180, \$§ 1, 2. An Idaho statute abandons the presumption of fertility under a suspension of the power of alienation rule. IDAHO Code ANN. § 55-111 (1957); Sparks, Future Interests, 33 N.Y.U.L. REv. 390, 395 (1958).

12 See note 3 supra. 
ments of the Rule has been made mandatory in some situations where the Rule has been violated.13

7) Contingent future interests in certain designated groups of persons have been exempted from the operation of the Rule.14

Nearly all of the legislative changes in the Rule were anticipated by the courts 15 and, indeed, in some respects the courts have outdistanced the legislatures in discarding the accumulated rubbish from a thousand years' evolution of property law.16

After little more than a decade of minimal discussion of proposals for reform, ${ }^{17}$ and of relatively restricted change effected as a result of that discussion, what can be said with respect to the wisdom of the new legislation and the likelihood of its general adoption?

First, it should be conceded that Leach's all-out attack on the Rule rests firmly on a group of precedents that undeniably attained outrageous results more often than not. One may deplore them, but indignation will not in itself effect their disappearance. They are a part of our inheritance, and they unquestionably lend impressive weight to Leach's arguments for reform. But Leach's position with respect to reforming the Rule is that of the advocate. His briefs are persuasive, but they are not invulnerable.

Many of the perpetuities cases invoking the contempt and ridicule of several generations of lawyers are old.18 That they served to shape the Rule is common knowledge. They are included in casebooks, taught in classrooms, and alluded to in texts. They do pose a continuing threat to dispositive provi-

13 Vt. Stat. AnN. tit. 27, $\$ \$ 501-03$ (1959); Wash. Rev. Code tit. 11, $\$ \$ 11.98 .010-.030$ (1959); Ky. Acts 1960, S. 180, $\$ \$ 1,2$. An Idaho statute applies cy pres to trust instruments violating a rule against suspension of the power of alienation. IDAHO CODE ANN. §55-111 (1957); Sparks, supra note 11.

$141 \mathrm{CCH}$ Pens. Plan Guide $\$ 1116$ (1960).

15 E.g., Edgerly v. Barker, 66 N.H. 434 (1891) (a gift to grandchildren of the testator who should be alive when the youngest reached 40 saved by cutting the age to 21). See Quarles, The Cy Pres Doctrine: Its Application to Cases Involving the Rule Against Perpetuities and Trusts for Accumulation, 21 N.Y.U.L. REv. 384 (1946). Occasional misgivings about cutting down age contingencies have had no appreciable effect. Freund, Three Suggestions Concerning Future Interests, 33 HARV. L. REV. 526, 533 (1920) ("A gift at twenty-one is not logically included in a gift at twenty-five, because the former is a larger gift, and the more is not included in the less.")

16 E.g., Brown v. Terra Bella Irrigation District, 51 Cal.2d 33, 330 P.2d 775 (1958); Brown v. Independent Baptist Church of Woburn, 325 Mass. 645, 91 N.E.2d 922 (1950). These cases are discussed in the text infra at notes 20-24.

17 Professor Schuyler has suggested the abandonment of the "vesting" test for validity under the Rule and the substitution of a possessory test. His proposals are set forth in an excellent article. Schuyler, Should the Rule Against Perpetuities Discard Its Vest ? (pts. 1-2), 56 Mich. L. REv. 683, 887 (1958). Although the suggestion received Professor Simes' earlier qualified endorsement, Simes, PUBlic POLICY AND THE DeAd HaNd 80 (1955), it has not been given legislative recognition.

18 Unfortunately a few are new. E.g., Re Gaite's Will Trusts, [1949] 1 All E.R. 459 (Ch.). 
sions of deeds, declarations of trust, and wills. It is doubtful, however, that the threat is as formidable today as it perhaps once was. Gray's classic formulation of the Rule19 came at a time when property law made up much of a lawyer's learning. That day is over. The passing of the pre-eminence of property law requires no elaborate documentation, and that pre-eminence was the very basis for the rigorous application of the Rule that Gray advocated. Consequently, Leach's brief for reform tells a story, but the account is incomplete.

\section{II}

For purposes of illustrating the jumps that modern courts are willing to take in perpetuities cases, consider Brown v. Terra Bella Irrigation District. ${ }^{20}$ In 1932 Halbert granted land to the defendant district with a "reservation" of "all oil and gas and all minerals in or underlying said real property." The deed further provided that the reservation should continue for the period of twentyfive years from the date of the delivery of the deed to the grantee "and as long thereafter as oil or gas or petroleum products or minerals shall be produced ... in paying quantities" and that "subject to the reservations and conditions aforesaid, [Halbert] hereby grants . . . all of said real property aforesaid to the [defendant district], together with . . . the reversion and reversions, remainder and remainders ... thereof."

In 1955 Halbert by quitclaim deed transferred to plaintiffs all the oil or gas "in and under, or that may be produced from" the real property involved, subject however, "to all of the terms, conditions, covenants and agreements" in the deed of 1932 from Halbert to the defendant district. In 1956 plaintiffs sought to quiet title. No oil, gas or minerals had been produced up to and including the commencement of the action.

Plaintiffs contended that the "reservation" contained in the deed of 1932 was really an "exception," that grantor Halbert had attempted to create a contingent future interest in the defendant district (a "remainder over") that would vest at a remote time-namely, at the expiration of twenty-five years and the cessation of production in paying quantities. The "remainder over" being bad under the Rule Against Perpetuities, title to the oil, gas and minerals remained in Halbert and passed to plaintiffs under the deed of 1955.

The Supreme Court of California found it unnecessary to resolve the plaintiffs' contentions, for even if they were right with respect to their analysis of the present and future interests arising out of the deed of 1932, and the invalidity of the latter under the Rule,

we would be required for other reasons to affirm the judgment [for defendant district]. It is obvious that if the plaintiffs' contentions are correct the grantor was ... possessed of a reversionary interest in the oil, gas and mineral rights to take effect

19 Gray, The Rule Agansst Perpeturties 191 (4th ed. 1942). The first edition appeared in 1886 .

2051 Cal.2d 33, 330 P.2d 775 (1958). 
in possession upon the expiration of his determinable estate after 25 years and the cessation of profitable production. The rule against perpetuities ... voids an attempted conveyance as of the time of the execution of the deed. [citation] In the present case an interest in the reversion was existent in the grantor upon the execution of the deed. Such an interest . . . is alienable by the grantor. [citation] It was in fact transferred to the district by the same deed which, the plaintiffs claim, failed to provide a valid remainder over. . . . As hereinbefore shown the deed provides for the transfer of the grantor's real property, "together with the ... reversion and reversions, remainder and remainders . . . thereof. ..." [T] he grantor intended to convey all of his reversionary rights to the district and . . . an effective conveyance thereof was made. 21

The result reached by the California court clearly carried out the intention of the parties to the deed of 1932. Furthermore, the opinion sanctioned accomplishing through one piece of paper what could have been done by two. But the case cannot be reconciled with Walker $v$. Marcellus and Otisco Lake Ry.,22 which invalidated under the Rule a remote excutory interest following an excepted determinable fee.

Brown v. Terra Bella Irrigation District involved an inter vivos transfer. Its counterpart in the testamentary field is Brown v. Independent Baptist Church of Woburn. ${ }^{23}$ There the testatrix in 1849 devised land to a church "so long as they shall maintain and promulgate their present religious belief and faith and shall continue as a Church," then to ten named persons who were also the residuary devisees. In 1939 the church ceased to exist. In a suit to determine whether the property passed to the successors in interest of the heirs at law of the testatrix or to the successors in interest of the residuary devisees, the Supreme Judicial Court of Massachusetts held that the gift over was void under the Rule Against Perpetuities. The possibility of reverter passed to the ten named persons under the residuary clause.

In neither the Irrigation District case nor the Woburn Church case is the equivalence of the executory interest and the possibility of reverter following a determinable fee conceded. Nothing is made of the fact that it is illogical under orthodox doctrine to invalidate an executory interest that might vest remotely and at the same time permit the transfer to a stranger of a possibility of reverter having the same characteristic of remoteness in fact if not in law.

Nevertheless, it is difficult to believe that the judges in both cases were unaware of what they were doing. Both decisions are explainable on technical grounds, but the technical explanations are unsatisfactory. As Simes dryly observed when discussing the Woburn Church case: "[The testatrix] did not

21 Id. at $36-37,330$ P.2d at 777.

22226 N.Y. 347, 123 N.E. 736 (1919).

23325 Mass. 64S, 91 N.E.2d 922 (1950); see 6 AMERICAN LAW OF ProperTY $\$ 24.62$ (Casner ed. 1952). 
die twice . . .."24 Certainly neither decision exemplifies the rigorous application of the Rule that brought forth Leach's scathing indictment.

Are these two cases aberrational? I doubt it. They may not represent the usual approach to solving perpetuities problems, but they are symptomatic of a discernible trend in case law. They do not stand alone. Consider, for example, contemporary handling of three kinds of cases frequently before the courts.

The "unborn widow" construction permits the invalidation of future interests under circumstances which do not normally warrant invocation of the Rule. A grantor, settlor or testator creates gifts to A for life, then to A's widow for life, remainder in fee simple to such of the children of A as survive the widow. Since A might marry a woman not in being at the effective date of the instrument of transfer, the ultimate gifts conditioned on surviving the widow of A are bad. Such is the standard view. 25

Even if counsel see the permissible construction inviting invalidity (and on occasion they miss it), courts are frequently quick to reject it. For example, in Willis $v$. Hendry 26 the testator created beneficial life interests in his residuary estate for designated persons including his son. Upon the death of the son, two-fifths of the income that the son would have been entitled to receive was to be paid to his wife if living with him at the time of his death. Upon the death of the wife, the income that she would have been entitled to receive was to be paid to the lawful issue of the son for 21 years in equal shares; and at the end of that period, the principal of the fund, "the income of which the wife of my son would have been entitled to receive," was to be paid to the lawful issue of the son then surviving; and if there were no lawful issue, principal was to be added to another trust. The trustees sought construction, asking whether the wife of the son referred to was the wife the son had when the testator died. The Supreme Court of Connecticut, noting that the testator had used the terms "the wife of my son" or "the wife of my said son" twelve times (rather than the indefinite "a wife" or "any wife"), construed the gift to be to the wife of the son in existence at the death of the testator even though only in her case had the testator failed to designate a living beneficiary by name.

Comparable cases are not difficult to find, 27 but the "unborn widow" construction has not lost all its vigor. In Disston's Estate 28 a testamentary gift to grandchildren of the testatrix surviving her sons "and their respective wives"

24 Simes, Is the Rule Against Perpetuities Doomed?, 52 Mrch. L. Rev. 179, n.4 (1953).

25 See Leach, Perpetuities in a Nutshell, 51 HaRv. L. Rev, 638, 644 (1938).

26127 Conn. 653, 20 A.2d 375 (1940).

27 In Batchelor Estate, 67 Pa. D. \& C. 310 (Orphans Ct. 1949), the court rejected the unborn widow construction because the testator using the generic expression in his will had specifically mentioned his daughter-in-law in a codicil. Gifts in remainder not being conditioned on surviving the widow, rejection of the construction was not essential to finding them good under the Rule.

2846 Pa. D. \& C. 496 (Orphans Ct. 1942). 
failed under the Rule, the court saying, "while possibly the testatrix intended the substitutionary gifts [of income] to the sons' wives to extend only to such wives as were living and married at testatrix's death [citations], yet there is no authority under which a woman born after testatrix's death and married to her son Horace could have been eliminated . . . ."29

So too with respect to the "fertile octogenarian" 30 and "administration contingency" constructions. Precedents support Leach's contention that the Rule is here little more than a trap for the draftsman, ${ }^{31}$ and judges in some recent opinions adhere to the older cases. ${ }^{32}$ But there are significant departures from the traditional approach. In Worcester County Trust Co. v. Marble 33 the testator died in 1901 survived by a sister Mary, then 84, unmarried and without issue, and by children of deceased brothers and sisters. He devised his residuary estate to his executors in trust, to pay the income to Sally (a sister of the testator who predeceased him), Mary, and a named niece, equally, and, ultimately, to the "nephews and nieces" of the testator and a specifically designated individual, equally. At the death of the survivor of the nephews, nieces, and the specifically designated individual, principal was to be divided "among those people who would be entitled to share" in the estate under the laws of Massachusetts. Mary died in 1906, unmarried. The named niece died in 1907. The individual specifically designated to share income with the nephews and nieces of the testator survived all of them and died in 1942. The trustee, seeking instructions, asked whether the "people who would be entitled to share" in

29 A gift of corpus to grandchildren of the testatrix surviving her son and his "widow" failed in Perkins v. Iglehart, 183 Md. 520, 39 A.2d 672 (1944).

30 The "fertile octogenarian" and "unborn widow" cases, though now characteristically separated (see Cohan, The Pennsylvania Wait-and-See Perpetuity Doctrine-New Kernels from Old Nutshells, 28 TEMP. L.Q. 321, 328 (1955); RUBENSTEIN, INTRODUCTION TO PERPETUITIES 11-12 (1959)), are variations on the same theme. In a gift to $A$ (a person alive at the effective date of the instrument) for life, then to A's children for their lives, remainder in fee to A's grandchildren, the ultimate gift is bad because A might have children born after the effective date of the instrument. But the gifts to $A$ and A's children (including afterborn children) are themselves good under the Rule. In a gift to $A$ (a person in being at the effective date of the instrument) for life, then to A's "widow" for life, remainder in fee to such of the children of $A$ as survive A's widow, the ultimate gift is bad because A's widow might be born after the effective date of the instrument. But the gifts to $\mathrm{A}$ and A's widow are themselves good under the Rule.

31 Leach, supra note 25, at 643.

32 In Honeywell Estate, 70 Pa. D. \& C. 472 (Orphans Ct. 1950), the testator created a testamentary trust for his only daughter for life. At her death principal was to be paid to her children when the youngest attained 25 , or, if at the time of distribution all her children were dead, to nephews and nieces of the testator. When the income beneficiary sought termination of the trust and distribution of principal to her because income was insufficient to support her, she was 62 years old and had had a hysterectomy. Her three children were all over 25. The gifts of principal were held void under the Rule, but invalidity was not essential to the decision ordering immediate termination of the trust. The daughter of the testator was found to be the primary beneficiary of the trust. Since the income of the trust was inadequate to provide for her, the testator's intention could be enforced only by awarding her the principal forthwith.

33316 Mass. 294, 55 N.E.2d 446 (1944). 
the estate under the laws of Massachusetts were to be determined as of the date of the testator's death or as of the time of termination of the trust in 1942. In determining that no violation of the Rule Against Perpetuities had occurred, The Supreme Judicial Court of Massachusetts said, "the will was executed about two years before the death of the testator. He must be taken to have known that his sister Mary was then about eighty-two years of age and was unmarried and had no issue, that all his other brothers and sisters, except his sister Sally ... had deceased, and that there was no possibility that through the deceased brothers and sisters there could be any nephews or nieces other than those living when the testator executed the will. ... [W] are of the opinion that the testator was providing for his sisters and for the nephews and nieces living at his death ...."34

A more striking example of the same constructional approach to reforming the Rule is In re Estate of Snyder. 35 When the testator executed his will in 1911 he had two living children, Andrew, 53, and Elizabeth, 58. Andrew had had one son who died before the will was executed. Elizabeth had three daughters living at the time of execution. The testator died in 1919. The will created a trust of the residuary estate, income being payable to Andrew and Elizabeth for their lives and the life of the survivor, then to the grandchildren in equal shares for their lives, "and ... immediately after the death of each of my grandchildren as it shall occur, then ... to pay ... unto all of my great grandchildren, living at ... the death of such grandchild ... per capita ... the share ... of my estate... held in Trust for the grandchild so dying." Following the deaths of Andrew, Elizabeth, and one of the daughters of Elizabeth, the trustee sought construction to determine how to distribute the share of corpus from which the deceased daughter of Elizabeth had received income. In disposing of a contention that the gifts of corpus violated the Rule Against Perpetuities (Andrew or Elizabeth might have a child or children after the testator's death, and such after-born child or children might have a child qualifying for gifts of corpus), the Court of Appeals of Maryland concluded that the testator's use of the pronoun "she" when referring to grandchildren justified the inference that he meant only those grandchildren whom he knew at the time of execution "and not ... other possible but improbable grandchildren who might come along later." Wright's Estate ${ }^{36}$ was cited with approval.37

34 "Thus we have a case where an estate which on its face obviously violated the Rule was saved by a construction adopted to carry out the presumed intention of the testator. I suppose only a lawyer steeped in the technicalities of the common law would criticize it." Newhall, Nibbling at the Rule Against Perpetuities, 29 Mass. L.Q. No. 3, 29, 30 (1944).

35195 Md. 81, 72 A.2d 757 (1950).

$36284 \mathrm{~Pa} .334,131$ Atl. 188 (1925) (trustees of testamentary trust given discretion to pay income to testator's "nieces and nephews"; class construed to include only children in being at the testator's death inasmuch as his brothers were then of advanced age).

37 In Lare's Estate, 57 Pa. D. \& C. 163 (Orphans Ct. 1946), Barnsley's Estate, 59 Pa. D. \& C. 653 (Orphans Ct. 1947), and Leonard's Estate, 60 Pa. D. \& C. 42 (Orphans Ct. 
In Smith v. Renne, ${ }^{38}$ a case reminiscent of Belfield v. Booth, ${ }^{39}$ the Supreme Court of Illinois rejected the "administration contingency" construction. There the testatrix put her residuary estate in trust "to be held for a period of 5 years or until such time as in [the trustees'] opinion it could be sold to best advantage.... When all the Real Estate has been sold then the Trustees will pay to each of the following the sum of $\$ 300 \ldots$. . [naming them] . . the remainder of the estate to be invested and held as a Trust fund, the income from which to be divided as follows: [five-sixths to church missions, one-sixth to Mrs. Rose Renne for life, then to a church mission]." In a construction proceeding brought by the executor, heirs of the testatrix argued that the gift to the missions violated the Rule because the sale might not occur within twentyone years from the time of the testatrix's death. The court thought otherwise. The testatrix intended the sale to take place as soon as convenient. It was unreasonable to think she intended the beneficiaries of the $\$ 300$ gifts to wait twenty-one years to obtain them. Encumbrances on the real estate would require prompt action by the trustees. In any event, sale within a reasonable time was required, and a reasonable time would be less than twenty-one years.

Judicial excision of a provision deferring sale until a conceivably remote time may save a gift. In Blake-Curtis v. Blake ${ }^{40}$ the testator directed his executor to preserve his estate and not to sell until he could realize $\$ 20$ per acre or the aggregate sum of $\$ 40,000$ "to be used as I direct." Proceeds of sale were to be distributed in designated fashions among the testator's children and grandchildren. In a will construction proceeding all parties agreed that the provision deferring sale violated the Rule, but two of the principal beneficiaries under the will argued successfully that the restriction on sale could be deleted without destroying the entire testamentary scheme.

In Myers v. Hardin ${ }^{41}$ the testatrix left her residuary estate to an individual

1947), the court ordered termination of a trust at the request of the life beneficiary where the vesting of a remainder in such beneficiary's issue was precluded by the unlikelihood of her having children and no other person or possible person had any interest in corpus. In Lare's Estate, petitioner was 69 , had never had children, was past the menopause, and in ill health. In Barnsley's Estate, she was 58, had never married nor given birth to a child, was past the menopause, and in ill health. In Leonard's Estate, she was 57, unmarried and without issue. Expert medical testimony to the effect that she could not conceive or bear a child was received. These cases are cited in Note, 26 TEMP. L.Q. 148 (1952), as authority for the proposition that the fertile octogenarian doctrine did not obtain in Pennsylvania at about the time the perpetuities legislation referred to in note 9 supra was enacted. Ideally the rejection of the doctrine in trust termination cases should be extended to perpetuities cases, but courts might differentiate on the basis of the context in which the question of indulging the conclusive presumption of fertility arises.

38382 Ill. 26, 46 N.E.2d 587 (1943).

3963 Conn. 299, 27 Atl. 585 (1893) (gift conditioned on the executor's settling with the judge of probate upheld).

40149 Kan. 512, 89 P.2d 15 (1939).

41208 Ark. 505, 186 S.W.2d 925 (1945). 
in trust with broad powers to sell, invest, and reinvest and to distribute from principal "as soon as possible" gifts in specific amounts to a sister (who predeceased the testatrix), a half-brother, a Catholic cemetery, and sixteen others, any excess after payment of such gifts to be paid "to my sisters and brothers; the survivor or survivors of them, share and share alike." Heirs argued a violation of the Rule, but the Supreme Court of Arkansas said that distribution as soon as possible meant "with due diligence and without unnecessary delay in the circumstances, and certainly within the lifetime of the trustee." 42

The impact of the doctrine can be avoided altogether by characterizing future interests as "vested" and making a discussion of the doctrine irrelevant. In Hodam v. Jordan 43 the testator devised property to two of his sons, James and Charles, in trust with powers in the trustees enabling them to pay off encumbrances on the lands from income "as soon as convenient." After the encumbrances were removed, income was to be divided equally among the testator's children, and in case of the death of any of them, equally among "the heirs." After the deaths of three specifically designated children and removal of the encumbrances, corpus was devised to the testator's "said grandchildren and to the heirs of Charles ... and ... James ..., the heirs of each taking the share... such deceased parent would take had not this will been made ... it being my intention by this will that at that time and not before, the title to said real estate shall vest in the heirs of my children or their descendants ...." The encumbrances were paid off. All five children of the testator died. Plaintiff, an alleged successor in interest of a son of James who had gone bankrupt, sought partition. The bankrupt contended that his interest under the will of his grandfather was a contingent interest which had not passed to the trustee in bankruptcy. A United States District Court in Illinois found that "heirs of my children or their descendants" meant "grandchildren or their descendants" and that the grandchildren of the testator took a vested remainder at his death, subject to divestment. Therefore the interest of the

42 Id. at 511, 186 S.W.2d at 928 . In Cambron v. Pottinger, 301 Ky. 768, 193 S.W.2d 412 (1946) the testator's will stated "At my death I want all my debts paid first. I then assign to my wife . . . all my . . . property. At her death I will to St. Annes Church $\$ 1,000.00$ the remainder of the estate to be divided equally between my heirs and the heirs of my wife." Although the Court of Appeals of Kentucky sustained the will when attacked under the Rule, it is far from clear that the "administration contingency" construction was advanced by counsel. In Emerson v. Campbell, 32 Del. Ch. 178, 84 A.2d 148 (1951), the testator directed the trustee of his residuary estate to pay to Alice P. Brown from income and corpus $\$ 6,000$ in equal monthly installments of $\$ 50$ each beginning three months after the testator's death. Should the trustee be able to effect a final distribution of the estate, the balance of the $\$ 6,000$ was payable forthwith. The Vice-Chancellor of Delaware found no violation of the Rule. The monthly payments were due a person in being at the testator's death and were, taken alone, valid. The provision for payment of the balance when final distribution was effected did not make the $\$ 6,000$ bequest remote. "In fact, it accelerates the payment." $I d$. at $193,84 \mathrm{~A} .2 \mathrm{~d}$ at 155 .

4382 F. Supp. 183 (E.D. Ill. 1949). 
bankrupt was valid under the Rule and passed to the trustee in bankruptcy through whom plaintiff traced title. 44

There are, however, cases reflecting the discredited approach. In Estate of Campbell 45 the testator gave his residuary estate to the four chair officers of a lodge "being the four chair officers in office at the time of distribution of my estate," free of trust, but with the expectation that they would devote the property to charitable purposes. Chair officers were elected annually, and those holding positions at the time of distribution of the estate were not those occupying the chairs at the testator's death. The gift failed because distribution might be deferred beyond the period in gross. A California District Court of Appeals refused to accept "a high degree of probability [of distribution within the time required] as a certainty."

\section{III}

One of the basic arguments against the adoption of "wait and see" legislation, namely, that wait and see means precisely that-deferring determination of the validity of an interest until actualities have occurred-is difficult to meet effectively. 46 There is much to be said for getting controversies settled, and there is no remarkably persuasive reason for excepting perpetuities problems in this respect. It is a fact that Pennsylvania even before 1947 did refuse to pass upon the validity of contingent future interests following life interests prior to the time the life interests had ended, 47 but that is hardly a justification for other states' adopting such a relatively poor practice. Furthermore, the Pennsylvania technique did not save gifts that were bad under the Rule as usually applied. Rather, it deferred determination of validity and nothing more.

An additional argument against promoting adoption of the Pennsylvania

44 In Estate of Swingle, 178 Kan. 529, 289 P.2d 778 (1955), gifts of income to three specifically named persons "provided . . . oil, gas or other minerals are produced" on designated tracts of land were saved from attack under the Rule, the Supreme Court of Kansas finding that the property "vested" at the death of the testatrix. If the donee must survive the resolution of the contingency, the gift is good. A gift to the grandmother of the testatrix if she should live on "to receive on distribution of my estate the property hereby bequeathed and devised to her" was upheld in McCollum's Estate, 43 Cal. App. 2d 313, 110 P.2d 721 (1941).

4528 Cal. App. 2d 102, 82 P.2d 22 (1938). See Note, 27 CalIF. L. Rev. 86 (1938); Note, 37 MiCH. L. REV. 814 (1939).

46 See Simes, Is the Rule Against Perpetuities Doomed?, 52 Mich. L. REV. 179, 184 (1953).

47 See, e.g., Quigley's Estate, 329 Pa. 281, 198 Atl. 85 (1938); Reed's Estate, 342 Pa. 54, 19 A.2d 365 (1941); Miller Trust, 351 Pa. 144, 40 A.2d 484 (1945); Laucks Estate, 358 Pa. 369,57 A.2d 855 (1948). Mechem doubts that the practice is widespread. Mechem, Further Thoughts on the Pennsylvania Perpetuities Legislation, 107 U. PA. L. REv. 965,979 (1959). There are occasional cases postponing resolution of the perpetuities problem. E.g., Industrial Trust Co. v. Wilson, 61 R.I. 169, 200 Atl. 467 (1938); In re Herrmann, 130 N.J. Eq. 273, 22 A.2d 262 (Prerog. Ct. 1941). 
legislation is that it has provoked respectable opposition, making persuasion of legislators difficult. 48 If substantial reformation of the Rule is attainable without prolonged controversy, there is no point to furthering highly contentious proposals.

The limited "wait and see" legislation is questionable on another ground. It continues an indefensible distinction between executory interests, on the one hand, and possibilities of reverter and rights of entry, on the other. ${ }^{49}$ Also, it presupposes the existence of limitations with respect to which differentiation can readily be achieved, and an ability of counsel and court to detect and appreciate the distinctions hit upon. 50 Case law casts doubt on the orthodox view of the categories of future interests and certainly demonstrates that draftsmen do not uniformly follow the formulae suggested by the Restatement of Property for the creation of such interests. 51

Rather than seek enactment of highly controversial statutes radically changing the common law Rule, property lawyers interested in improving the law might more profitably move along the following lines simultaneously.

1) Promote the adoption of statutes stating a preferred rule of construction in particular instances where the common law Rule has been severely criticized. The Real Property, Probate and Trust Law Section of the American Bar Association has suggested statutes designed to meet certain kinds of cases that have come under fire. 52

2) Encourage the simplification of the categories of future interests through both legislation and judicial decision. Authorities differ with respect to the requirement that an executory interest (unlike a contingent remainder) become possessory within the period of the Rule or fail. ${ }^{53}$ There being no persuasive argument for differentiating between the two interests for perpetuities purposes, the orthodox notion should be rejected. Likewise the equivalence of the possibility of reverter, the right of entry for condition broken, and the executory interest should be recognized.

${ }^{48}$ See Simes, supra note 46; Mechem, supra note 47; Sparks, Future Interests, 1955 ANN. SURVEY OF AMER. LAW 517, 526.

${ }^{49}$ See note 3 supra.

so "Violations are occurring all the time, and moreover, probate courts apparently pay no attention ... unless there is a contest, but often distribute property under a will clause which is void on its face." Coil, Perpetuities and Restraints; A Needed Reform, 30 ST. BAR J. CAIIF. 87, 88 (1955).

51 See Lynn \& Ramser, Applying the Rule Against Perpetuities to Functional Equivalents: Copps Chapel and the Woburn Church Revisited, 43 IowA L. REv. 36 (1957); Lynn \& Van Doren, Applying the Rule Against Perpetuities to Remainders and Executory Interests, 27 U. CHI. L. Rev. 436 (1960).

52 See ABA Legislators' Handbook on Perpetuities 12-15 (1958).

53 See Gray, The Rule Against Perpetuities $\$ 114$ (4th ed. 1942) for the traditional view, and CAREY \& SCHUYLER, ILlinOIS LAW OF Future INTERESTS $\S \S 474(1941), 480$ (Cum. Supp. 1954) for the less orthodox position. 
3) Reinforce the recognition of substance over form by approving and following decisions rejecting differences based on irrelevant choice of method. 54

4) Recognize the freedom made available to a court by the rules of construction. Urge a construction saving gifts for dependents or the community unless an intention to tie up property beyond permissible limits is palpable.

5) Seek the amendment of defective perpetuities statutes.

6) Stress drafting techniques that avoid bringing the application of the Rule into question. Lawyers must cope with the homemade will as they find it, but they do both their clients and themselves a disservice when they silently acquiesce in the creation of future interests inappropriate for solving the drafting problem before them. There is often much to be said for avoiding postponed gifts altogether, and especially so as non-traditional means for providing for dependents become commonplace.

\section{CONCLUSION}

The Rule Against Perpetuities needs revision, and there is nothing to be said for postponing modification indefinitely until differences of opinion respecting methods of reform are reconciled. But the Rule ought not to be blamed for faults inherent in the future interests hierarchy. Indefensible differentiations among contingent remainders, executory interests, possibilities of reverter, rights of entry for condition broken, and resulting trusts either antedate the Rule or developed contemporaneously with it. The complexities introduced by the indestructible trust doctrine are of relatively recent origin. 55 Certainly there is nothing in the generalized language of Lord Nottingham in the Duke of Norfolk's Case56 to justify the judicial ruthlessness dramatized so effectively by Professor Leach when parading his horribles through the pages of the Harvard Law Review. For every case serving as a reminder that the Rule needs improvement there are many showing that it works fairly well when handled intelligently by counsel and court. 57

\footnotetext{
54 Brown v. Terra Bella Irrigation Dist., 51 Cal. 2d 33, 330 P.2d 775 (1958), discussed supra at notes 20-22.

55 Claflin v. Claflin, 149 Mass. 19, 20 N.E. 454 (1889), established the doctrine in Massachusetts.

563 Ch. Cas. 1, 22 Eng. Rep. 931 (1682).

57 In Stanton v. Stanton, 140 Conn. 504, 101 A.2d 789 (1953), the testator left his interest in a corporation to one Clarence Ralph "upon condition . . . that he shall pay to my estate one-third of the net yearly income ... for ... such time as it shall continue in operation and upon its sale or liquidation shall pay to my estate one-third of the net sale price or liquidation value." The residuary estate was left in trust to use income (and corpus if necessary) to maintain the family home as a memorial to the testator's father and mother "and for the benefit of their descendants as long as there shall be any such descendants living" and to aid poor and worthy descendants. In a will construction proceeding the Supreme Court of Connecticut found no violation of the Rule. The disposition to Ralph reserved no property interest in the testator's estate but merely created a personal obligation in Ralph that the testator meant to last no longer than Ralph's lifetime. The provision for maintaining the family home was intended by the testator to benefit only descendants of his father and mother alive
} 
Whatever form the Rule takes, there are likely to be cases which apply it badly. There is no reason to believe that from the great mass of litigation before the courts perpetuities problems will be singled out for adroit disposition. Therefore the most that can be hoped for as a result of modification of the Rule is improvement in applying an expression on community policy that is itself a compromise of conflicting notions with respect to the disposition of property.

Until it is changed, this much can be gleaned from a reading of modern perpetuities cases: Although the Rule is far from perfect in conception ${ }^{58}$ and application, it is doubtful that it exists today in Gray's classic form, recent legislation apart. The meticulous characterization of future interests required as a prerequisite to applying Gray's Rule seldom obtains today. On the contrary, limitations that on orthodox grounds might be classified as contingent are called vested with little or no justification advanced or deemed necessary. Interests once carefully differentiated are consciously or unconsciously assimilated. Evidence accumulates casting doubt on the traditional notion that an executory interest must become possessory within the permissible period. The occasions for indulging fantastic possibilities are fewer in number. It is not unusual to find one piece of paper now doing tasks once thought impossible or at least achievable only through two. 59 The proportion of quasi-public wealth

at his death. In another recent case, the testator created a testamentary trust for his wife and daughter for their lives and directed that "as soon as possible" after their deaths principal be turned into cash and used for designated public purposes including the purchase of lots for park additions and the enhancement of the funds of a foundation if "after . . . careful study my executor is convinced that all funds coming into its treasury will be safely and prudently administered." Funds not transferred to the foundation were to be used for park improvements. The widow of the testator having died, his daughter sought principal as sole heir of her father, contending that the charitable gifts violated the Rule. All withstood attack, the Supreme Court of Kansas finding them "vested" at the testator's death. The intention to benefit the public in one way or another being clear, the result reached is defensible for mere administrative directions regarding the precise disposition from time to time of charitable wealth already vested in the public are not thought to create a perpetuities problem; but arguably the gifts to the foundation and for park improvements were both bad. They were subject to a determination by the executor which might occur remotely. In re Trust Estate of Woods, 181 Kan. 271, 311 P.2d 359 (1957).

58 See 1 Lord Nottingham's Chancery Cases Ixxiii (Yale ed., Selden Society 1957).

59 See Brown v. Independent Baptist Church of Woburn, 325 Mass. 645, 91 N.E.2d 922 (1950). In Knowles v. South County Hosp., 140 A.2d 499 (R.I. 1958), the testator devised realty to Knowles for life, remainder to his oldest heir, but subject to conditions ending when the remainderman attained 40 . Failure to comply with the conditions would result in the property "becoming and remaining part of [the testator's] estate, whereupon it is to be bequeathed to the Rhode Island State College ...." There was a residuary devise to the Rhode Island State College, Brown University, and the South County Hospital. The university and the hospital attacked the gift over to the college on the ground that it violated the Rule. The Supreme Court of Rhode Island avoided any perpetuities problem by refusing to call the gift over an executory devise. The "reversion" retained by the testator in the event of breach of the condition passed to the college. 
either specifically excepted from the operation of the Rule or subjected to it only imperfectly60 is increasing.

In short, the Rule has been up-dated through the interplay of inextricably intertwined factors: ignorance or indifference or adroitness of counsel and court, impatience of powerful groups with inappropriate rules of property, the press of more important problems requiring attention. Whatever are the reasons for de-emphasis, the Rule is hardly the threat it once was. There is no bogeyman-even in Massachusetts.

60 "Courts require less to constitute a vesting when a charity is the beneficiary." Note, 27 RoCKY MT. L. REv. 103, 104 n.13 (1954). 